\title{
Gestational Stress Promotes Pathological Apneas and Sex-Specific Disruption of Respiratory Control Development in Newborn Rat
}

\author{
Stéphanie Fournier, ${ }^{1}$ Shelby Steele, ${ }^{2}$ Cécile Julien, ${ }^{1}$ Sébastien Fournier, ${ }^{1}$ Roumiana Gulemetova, ${ }^{1}$ Céline Caravagna, \\ Jorge Soliz, ${ }^{1}$ Aida Bairam, ${ }^{1}$ and Richard Kinkead ${ }^{1}$ \\ ${ }^{1}$ Department of Pediatrics, Faculty of Medicine, Université Laval, Centre de Recherche du CHU de Québec, Hôpital St-François d'Assise, Québec City, \\ Québec, Canada, G1L 3L5, and 2Department of Biochemistry, Microbiology, and Immunology, Faculty of Medicine, University of Ottawa, Ottawa, Ontario, \\ Canada K1N 6N5
}

Recurrent apneas are important causes of hospitalization and morbidity in newborns. Gestational stress (GS) compromises fetal brain development. Maternal stress and anxiety during gestation are linked to respiratory disorders in newborns; however, the mechanisms remain unknown. Here, we tested the hypothesis that repeated activation of the neuroendocrine response to stress during gestation is sufficient to disrupt the development of respiratory control and augment the occurrence of apneas in newborn rats. Pregnant dams were displaced and exposed to predator odor from days 9 to 19 of gestation. Control dams were undisturbed. Experiments were performed on male and female rats aged between 0 and $4 \mathrm{~d}$ old. Apnea frequency decreased with age but was consistently higher in stressed pups than controls. At day 4, GS augmented the proportion of apneas with $\mathrm{O}_{2}$ desaturations by $12 \%$. During acute hypoxia $\left(12 \% \mathrm{O}_{2}\right)$, the reflexive increase in breathing augmented with age; however, this response was lower in stressed pups. Instability of respiratory rhythm recorded from medullary preparations decreased with age but was higher in stressed pups than controls. GS reduced medullary serotonin (5-HT) levels in newborn pups by $32 \%$. Bath application of 5-HT and injection of 8-0H-DPAT [( \pm )-8-hydroxy-2-di-(n-propylamino) tetralin hydrobromide; 5 - $\mathrm{HT}_{1 \mathrm{~A}}$ agonist; in vivo] reduced respiratory instability and apneas; these effects were greater in stressed pups than controls. Sex-specific effects were observed. We conclude that activation of the stress response during gestation is sufficient to disrupt respiratory control development and promote pathological apneas in newborn rats. A deficit in medullary 5-HT contributes to these effects.

\section{Introduction}

Recurrent apneas and respiratory instabilities are important causes of hospitalization and morbidity in premature newborns. Because the respiratory control system undergoes important development during early life, neonatal apneas typically resolve themselves by $36-40$ weeks after conception. However, $\sim 10 \%$ of healthy premature infants and $\sim 5 \%$ of infants born at term show apneic events with $\mathrm{O}_{2}$ desaturations and bradycardias beyond this time (Poets, 2010; Hunt et al., 2011), and newborn males are more at risk of developing respiratory disorders than females (Mage and Donner, 2006). Despite its impact on infant morbid-

Received March 12, 2012; revised 0ct. 29, 2012; accepted Nov. 6, 2012.

Author contributions: St.F., J.S., A.B., and R.K. designed research; St.F., S.S., C.J., Se.F., R.G., and C.C. performed research; St.F., S.S., C.C., J.S., and A.B. contributed unpublished reagents/analytic tools; St.F., S.S., C.J., C.C., and R.K. analyzed data; St.F., A.B., and R.K. wrote the paper.

This research was supported by Canadian Institutes of Health Research Grants MOP 119337 (R.K.) and MOP 119272 (A.B.), the Canada Research Chair in Respiratory Neurobiology (R.K.), and the Foundation of Stars. We thank Hélène Crépeau (consultant in statistics, Department of Mathematics, Université Laval, Québec City, Québec, Canada) and Mélanie Pelletier and Sylvie Viger (animal care specialists).

The authors declare no competing financial interests.

Correspondence should be addressed to Dr. Richard Kinkead, Centre de Recherche (D0-711), Hôpital St-François d'Assise, 10 rue de l'Espinay, Québec, Québec, Canada G1L3L5. E-mail: Richard.Kinkead@crsfa.ulaval.ca.

DOI:10.1523/JNEUROSCI.1214-12.2013

Copyright $\odot 2013$ the authors $\quad 0270-6474 / 13 / 330563-11 \$ 15.00 / 0$ ity, our understanding of such heterogeneity in respiratory control development remains limited.

Exposures to hypoxia, nicotine, or cocaine during gestation are established disruptors of respiratory development in newborns, and the mechanisms underlying their effects are diverse. However, considering that these stressors can stimulate corticosterone release in the mother (Damianopoulos and Carey, 1995; Stanulis et al., 1997) and that gestational stress (GS) or antenatal maternal anxiety is a risk factor for several neurological diseases (Talge et al., 2007; Field and Diego, 2008; Kinney et al., 2008), elevated stress hormones during gestation may be a common pathway that leads to disrupted ventilatory control in newborns. Little is known about the impact of stress hormones per se on respiratory control development. However, high maternal cortisol levels during pregnancy have been associated with an increased need for resuscitation measures at birth (Ponirakis et al., 1998). Furthermore, maternal anxiety and substance abuse exacerbate apneic events in the newborn and are established risk factors for sudden infant death syndrome (SIDS) (Kinney and Thach, 2009). Although these clinical observations argue that maternal stress during gestation disrupts respiratory control development, confounding factors related to maternal age/lifestyle and overall health of the infant limit the conclusions that can be 
drawn from these studies. Here, we used an animal model to better control environmental variables and tested the hypothesis that recurrent activation of stress response in gestating dams is sufficient to disrupt respiratory control development and promote respiratory disorders in newborn rats. We first compared respiratory activity of pups born to undisturbed dams with those born to females exposed to stress during pregnancy. We measured apnea frequency and respiratory variability in both intact animals and reduced medullary preparations; we then quantified the hyperventilatory response to respiratory stimuli $\left(\mathrm{CO}_{2}\right.$ and hypoxia). Experiments were performed on males and females to assess sex-specific effects. At postnatal day 4 (P4), the physiological impact of GS was assessed by using pulse oxymetry to determine whether apneic events were associated with $\mathrm{O}_{2}$ desaturations and bradycardias.

Besides promoting neural development during early life (Hodges and Richerson, 2008), serotonin (5-HT) exerts a profound influence on respiratory rhythm and its stability (Richter et al., 2003). Consequently, abnormal 5-HT modulation of respiratory networks has been implicated in respiratory disorders, including SIDS (Hilaire et al., 2010). Because stress interferes with development and function of 5-HT neurons (Vázquez et al., 2000; Papaioannou et al., 2002), we determined whether disruption of 5-HT modulation contributes to the higher apnea frequency observed in pups born from stressed dams.

\section{Materials and Methods}

Animals

Experiments were performed on male and female Sprague Dawley rats aged between 0 and $4 \mathrm{~d}$ (P0, P2, and P4). These pups were born from 97 virgin females mated in our animal care facility. Dams were supplied with food and water ad libitum and maintained in standard animal care conditions $\left(21^{\circ} \mathrm{C}, 12 \mathrm{~h}\right.$ light/dark cycle: lights on at 7:00 A.M. and off at 7:00 P.M.). All experiments complied with the guidelines of the Canadian Council on Animal Care. The institutional animal care committee approved the specific protocols used in this study.

\section{GS procedures}

After mating, pregnancy was confirmed by vaginal smear [gestation day 0 (G0)]. Novelty, bright light, and predator odor activate the neuroendocrine response to stress in rodents (Chandramohan et al., 2007; Fendt and Endres, 2008). On G9, dams assigned to GS protocol were transported outside the animal care facility and placed in a brightly lit room in a clean cage (one dam per cage), each containing a piece of filter paper wetted with $35 \mu \mathrm{l}$ of fox anal gland extract [2,5,-dihydro-2,4,5,trimethylethiazoline (TMT)] (Pherotech). This predator odor induces fear and activates the neuroendocrine response to stress in rodents (Fendt and Endres, 2008). The protocol was performed at 9:00 AM daily from G9 to G19 and lasted 20 min. The stress procedure was performed under a fume hood located outside the main animal housing facility. At the end of the procedure, the TMT impregnated paper was removed from the cage, and a blood sample was taken (see below). Because the predator odor was still perceptible at that time, the dam remained in the experimental cage under the fume hood for $1 \mathrm{~h}$ before being returned to the animal care facility. Performing TMT exposure outside the animal care facility was necessary to prevent exposing other animals that were not part of the stress protocol. Accordingly, unstressed (control) dams remained in the animal care facility where they were not disturbed (except for regular care) throughout gestation.

\section{Corticosterone measurement}

At 9:20 AM on G12, a tail blood sample was taken either during normal care (control; $n=32$ ) or immediately after TMT exposure (GS; $n=54$ ). Blood collection and plasma corticosterone measurements were performed according to standard laboratory procedures (Fournier et al., 2007). Briefly, blood was transferred from the syringe into a tube containing EDTA (microvette 500; Sarstedt). Plasma was separated by cen- trifugation, quickly frozen at $-80^{\circ} \mathrm{C}$ until assayed. Corticosterone levels were determined by an enzyme immunoassay (Assay Design). Corticosterone detection was done with a microplate spectrophotometer $(\mu$ Quant; Bio-Tek Instruments). The corticosterone concentration was calculated from the four-parameter logistic standard curve using SigmaPlot 12.3 (Systat Software).

\section{Respiratory measurements in vivo}

Measurements of apneas, ventilatory activity, and basal $\mathrm{O}_{2}$ consumption $\left(\mathrm{V}_{2}\right)$ in newborn pups were performed using wholebody, flow-through plethysmography. Development of the hypoxic chemoreflex was compared between groups and sexes. The efficiency of the selective 5- $\mathrm{HT}_{1 \mathrm{~A}}$ agonist 8 -OH-DPAT [( \pm - -8 -hydroxy-2-di( $n$-propylamino) tetralin hydrobromide; $0.05 \mathrm{mg} / \mathrm{kg}$, i.p.] for the treatment of apneas was also compared. On P4, the physiological relevance of stress-related increase in apneic events was evaluated by (1) combining plethysmography with measurements of $\mathrm{O}_{2}$ saturation $\left(\mathrm{SpO}_{2}\right)$ and heart rate with pulse oxymetry, (2) measuring the ventilatory response to $\mathrm{CO}_{2}$, and (3) comparing basal corticosterone levels between groups.

Definition of apneas, desaturations, and bradycardias in rodents. There is no clear consensus regarding the clinical definition of pathological apneas in humans (Finer et al., 2006; Eichenwald et al., 2011). Thus, using a criteria commonly used in rodents (Han et al., 2002; Montandon et al., 2006; Zanella et al., 2008), an apnea was arbitrarily defined as an interruption of airflow for at least two breathing cycles (at P2 for instance, an apneic pause $>0.75 \mathrm{~s}$ ). The apnea frequency is the sum of both spontaneous and post-sigh apneas.

In the clinic, there is no consensus on the decrease of $\mathrm{SpO}_{2}$ or severity of bradycardia that should be considered pathologic (Finer et al., 2006). In rats, $\mathrm{O}_{2}$ desaturations and bradycardias were arbitrarily defined as a $5 \%$ fall below baseline (Bairam et al., 2012); however, the average $\mathrm{SpO}_{2}$ and heart rate decreases observed (see Fig. $8 B, C$ ) meet the $10 \%$ criteria often used in clinical studies (Ramanathan et al., 2001).

Whole-body plethysmography. These methods have been described previously (Gulemetova and Kinkead, 2011). Briefly, air flow through the chamber was set to $0.1 \mathrm{~L} / \mathrm{min}$, and temperature inside the chamber was maintained at $34^{\circ} \mathrm{C}(\mathrm{P} 0 / \mathrm{P} 2)$ or $32^{\circ} \mathrm{C}(\mathrm{P} 4)$ using a temperature control system (Physitemp). The system was calibrated by injecting a known volume $(0.5 \mathrm{ml})$ into the chamber with a glass syringe at a rate corresponding to the air flow range typically generated by rat pups. Barometric pressure, chamber temperature and humidity, and the body temperature of the pup $\left(\mathrm{T}_{\mathrm{b}}\right)$ were also measured in normoxia and at the end of hypoxia, hypercapnia, or the 8-OH DPAT protocol to correct the tidal volume $\left(\mathrm{V}_{\mathrm{T}}\right)$ and thus minute ventilation $\left(\dot{\mathrm{V}}_{\mathrm{E}}\right)$ and express values in milliliters BTPS (Drorbaugh and Fenn, 1955). Composition of the gas mixtures flowing in and out of the chamber was analyzed with an oxygen analyzer (model S-3A; Ametek) for subsequent calculation of $\dot{\mathrm{VO}}_{2}$ (Mortola and Dotta, 1992).

Measurement of $\mathrm{SpO}_{2}$ and bradycardias. An infrared emitter/sensor was placed around the neck of 4-d-old pups to measure $\mathrm{SpO}_{2}$ and heart rate (Mouse Ox; Starr Life Sciences). The pup was then placed in a plethysmography chamber to monitor apneas.

Apnea treatment with 8-OH-DPAT. The apnea frequency, $\mathrm{O}_{2}$ desaturations, and bradycardias were measured after intraperitoneal injection of saline or the selective $5-\mathrm{HT}_{1 \mathrm{~A}}$ agonist $8-\mathrm{OH}-\mathrm{DPAT}(0.05 \mathrm{mg} / \mathrm{kg})$.

Basal corticosterone and testosterone levels. Terminal blood samples were taken from 4-d-old pups that were not exposed to any stimulus or treatment. Sample handling and corticosterone measurement were performed according to the previously described methods (Fournier et al., 2011). Testosterone was measured in serum using an enzyme immunoassay (Cayman Chemical) and detected with a microplate spectrophotometer. The testosterone concentration was calculated with the spreadsheet provided by Cayman Chemical.

\section{Protocol and data analyses}

Normoxia. Each pup was first placed in the plethysmograph for $10 \mathrm{~min}$ to acclimatize to the chamber and ambient temperature. The chamber was briefly opened, and buccal temperature was measured with a small ther- 
Table 1. Comparison of body weights and selected physiological variables between pups born dams subjected to gestational stress versus pups born from undisturbed mothers (control)

\begin{tabular}{|c|c|c|c|c|c|c|c|c|c|c|}
\hline & \multicolumn{3}{|l|}{ Control } & \multicolumn{3}{|l|}{ Stress } & \multirow[b]{2}{*}{ Stress effect } & \multirow[b]{2}{*}{ Age effect } & \multirow[b]{2}{*}{ Sex effect } & \multirow[b]{2}{*}{ Factorial interaction } \\
\hline & PO & P2 & P4 & PO & P2 & P4 & & & & \\
\hline \multicolumn{11}{|l|}{ Body weight (g) } \\
\hline Female & $6.3 \pm 0.2^{\&}(15 ; 42)$ & $7.4 \pm 0.3^{* \&}(12 ; 36)$ & $10.5 \pm 0.3^{* \&}(24 ; 85)$ & $6.1 \pm 0.1^{\&}(16 ; 33)$ & $7.0 \pm 0.2^{* \&}(16 ; 47)$ & $10.3 \pm 0.2^{* \&}(27 ; 92)$ & $\begin{array}{l}p=0.30 ; \\
\quad F_{(1,86)}=1.1\end{array}$ & $\begin{array}{l}p<0.0001 ; \\
\quad F_{(2,670)}=743.8\end{array}$ & $\begin{array}{l}p<0.0001 ; \\
\quad F_{(1,609)}=39.9\end{array}$ & $\begin{array}{c}\text { Age } \times \text { sex } \times \text { stress, } p=0.02 ; \\
F_{(2,009)}=4.0\end{array}$ \\
\hline Male & $6.5 \pm 0.2(13 ; 40)$ & $8.0 \pm 0.2^{*}(12 ; 34)$ & $10.4 \pm 0.3^{*}(25 ; 97)$ & $6.4 \pm 0.1(\mathbf{1 6} ; 34)$ & $7.3 \pm 0.3^{*}(17 ; 40)$ & $10.8 \pm 0.3^{*}(30 ; 110)$ & $\begin{array}{l}p=0.30 ; \\
\quad F_{(1,86)}=1.1\end{array}$ & $\begin{array}{l}p<0.0001 ; \\
\quad F_{(2,670)}=743.8\end{array}$ & $\begin{array}{l}p<0.0001 ; \\
\quad F_{(1,609)}=39.9\end{array}$ & $\begin{array}{c}\text { Age } \times \text { sex } \times \text { stress, } p=0.02 ; \\
F_{(2,609)}=4.0\end{array}$ \\
\hline$f_{R}$ (breaths/min) & $145 \pm 2(4 ; 18)$ & $165 \pm 7^{*}(4 ; 21)$ & $169 \pm 5^{*}(10 ; 74)$ & $143 \pm 10(7 ; 26)$ & $167 \pm 7^{*}(9 ; 40)$ & $167 \pm 5^{*}(15 ; 96)$ & $\begin{array}{l}p=0.84 ; \\
\quad F_{(1,35)}=0.04\end{array}$ & $\begin{array}{l}p<0.0001 \\
\quad F_{(2,251)}=16.6\end{array}$ & $\begin{array}{l}p=0.58 ; \\
\quad F_{(1,245)}=0.3\end{array}$ & NS \\
\hline $\mathrm{V}_{\mathrm{T}}(\mathrm{ml} \mathrm{BTPS} / 100 \mathrm{~g})$ & $0.77 \pm 0.08$ & $0.93 \pm 0.09$ & $1.0 \pm 0.1$ & $1.3 \pm 0.1^{\dagger}$ & $0.90 \pm 0.14^{*}$ & $1.1 \pm 0.1^{*}$ & $\begin{array}{l}p=0.38 ; \\
\quad F_{(1,34)}=0.8\end{array}$ & $\begin{array}{l}p<0.0001 ; \\
\quad F_{(2,256)}=12.2\end{array}$ & $\begin{array}{l}p=0.10 ; \\
\quad F_{(1,237)}=2.8\end{array}$ & $\begin{array}{c}\text { Age } \times \text { stress, } p<0.0001 \\
F_{(2,256)}=15.3\end{array}$ \\
\hline$\dot{V} \dot{V}_{E}(\mathrm{ml} \mathrm{BTPS} / \mathrm{min} / 100 \mathrm{~g})$ & $111 \pm 12$ & $151 \pm 11^{*}$ & $174 \pm 23$ & $194 \pm 37$ & $156 \pm 30^{*}$ & $180 \pm 19^{*}$ & $\begin{array}{l}p=0.44 ; \\
\quad F_{(1,34)}=0.6\end{array}$ & $\begin{array}{l}p=0.01 ; \\
\quad F_{(2,257)}=4.4\end{array}$ & $\begin{array}{l}p=0.16 ; \\
\quad F_{(1,237)}=2.8\end{array}$ & $\begin{array}{c}\text { Age } \times \text { stress }, p<0.0001 ; \\
F_{(2,257)}=13.5\end{array}$ \\
\hline$\dot{\mathrm{V}} \mathrm{O}_{2}(\mathrm{ml} \mathrm{STPD} / \mathrm{min} / 100 \mathrm{~g})$ & $3.9 \pm 0.4$ & $4.9 \pm 0.1^{*}$ & $3.9 \pm 0.3$ & $4.3 \pm 0.3$ & $4.9 \pm 0.4^{*}$ & $4.1 \pm 0.3$ & $\begin{array}{l}p=0.64 ; \\
\quad F_{(1,37)}=0.2\end{array}$ & $\begin{array}{l}p=0.0005 \\
\quad F_{(2,227)}=7.8\end{array}$ & $\begin{array}{l}p=0.63 ; \\
\quad F_{(1,250)}=0.2\end{array}$ & NS \\
\hline$\dot{\mathrm{V}}_{\mathrm{E}} / \dot{\mathrm{N}}_{2}$ & $30 \pm 3$ & $33 \pm 3$ & $49 \pm 8$ & $49 \pm 9$ & $33 \pm 5^{*}$ & $47 \pm 4^{*}$ & $\begin{array}{l}p=0.63 ; \\
\quad F_{(1,33)}=0.2\end{array}$ & $\begin{array}{l}p=0.0008 ; \\
\quad F_{(2,257)}=7.3\end{array}$ & $\begin{array}{l}p=0.18 ; \\
\quad F_{(1,240)}=1.8\end{array}$ & $\begin{array}{c}\text { Age } \times \text { stress }, p<0.0001 ; \\
F_{(2,257)}=9.2\end{array}$ \\
\hline Body temperature $\left({ }^{\circ} \mathrm{C}\right)$ & $34.6 \pm 0.3$ & $33.9 \pm 0.6$ & $33.5 \pm 0.2^{*}$ & $33.8 \pm 0.4$ & $33.9 \pm 0.4$ & $33.1 \pm 0.2$ & $\begin{array}{l}p=0.26 ; \\
\quad F_{(1,36)}=1.3\end{array}$ & $\begin{array}{l}p=0.002 ; \\
\quad F_{(2,252)}=6.5\end{array}$ & $\begin{array}{l}p=0.51 ; \\
\quad F_{(1,245)}=0.4\end{array}$ & NS \\
\hline
\end{tabular}

Measurements were performed under normoxic conditions in three age groups. Number of litters (bold) and pups per group are reported in parentheses after body weights. Except for body weights, data from injected animals (8-0H-DPAT series) are not included. Because sex-related differences were observed only for body weights, results obtained from male and female pups were pooled for all other variables. Data are reported as means $\pm S E M$. ${ }^{*} p<0.05$, different from PO. ${ }^{\dagger} p<0.05$, different from corresponding control value. ${ }^{\circledR} p<0.05$, different from corresponding male value. NS, Not significant. BTPS, Body temperature, ambient pressure, saturated; STPD, Standard temperature and pressure, dry.

mocouple. $\mathrm{T}_{\mathrm{b}}$ was not monitored continuously to minimize physical stress during the measurements. The chamber was closed, and the baseline (normoxic) ventilatory and $\mathrm{VO}_{2}$ measurements were started once the animal was calm and the breathing activity was stable. This baseline period typically lasted $20 \mathrm{~min}$. Breathing frequency $\left(f_{\mathrm{R}}\right), \mathrm{V}_{\mathrm{T}}$, and $\mathrm{VE}$ were recorded using data acquisition software (IOX; EMKA Technologies). Baseline values of these variables were obtained by averaging results over the last $10 \mathrm{~min}$ that preceded hypoxia or hypercapnia.

Hypoxic ventilatory response. Moderate hypoxia was initiated after baseline measurement by adding $\mathrm{N}_{2}$ to the inflowing gas mixture. The target level of hypoxia $\left(\mathrm{FIO}_{2}=0.12\right)$ was reached within 2 min using preset gas mixing parameters to ensure that the hypoxia dynamic within the chamber was constant between experiments. Exposure lasted $20 \mathrm{~min}$. The hypoxic ventilatory response (HVR) was first assessed by averaging $f_{\mathrm{R}}$ over the first $8 \mathrm{~min}$ of hypoxia; this value was then expressed as a percentage change from the normoxic value. The HVR of newborn rats being biphasic (Saetta and Mortola, 1987; Bissonnette, 2000) (see Fig. 3A); this period was chosen because of our interest in obtaining a value reflecting the rapid increase in breathing associated with chemoreceptor activation at the onset of hypoxia. The late phase of the response was assessed by averaging values from the last 4 min of hypoxia (between minutes 16 and 20 of exposure).

Hypercapnic ventilatory response. Moderate hypercapnia $\left(\mathrm{FICO}_{2}=\right.$ 0.05 ) was initiated after baseline measurement by adding $\mathrm{CO}_{2}$ to the inflowing gas mixture. Exposure lasted $20 \mathrm{~min}$. The response was assessed by averaging values from the last $5 \mathrm{~min}$ of hypercapnia (between minutes 15 and 20 of exposure).

Effect of a 5-HT ${ }_{1 \mathrm{~A}}$ agonist (8-OH-DPAT) on apnea frequency. These experiments aimed to determine whether systemic administration of a $5-\mathrm{HT}_{1 \mathrm{~A}}$ agonist could alleviate apneas in newborn pups. Before being placed in the recording chamber, pups were injected (intraperitoneally) with vehicle (saline) or 8-OH-DPAT (Sigma-Aldrich) dissolved in saline. The selected dose was $0.05 \mathrm{mg} / \mathrm{kg}$, and the injected volume was $2 \mu \mathrm{l} / \mathrm{g}$. Preliminary experiments showed that this dose effectively reduces apneas with minimal effects on $f_{\mathrm{R}}$. Higher doses (e.g., $0.1 \mathrm{mg} / \mathrm{kg}$ ) augmented movement-related artifacts during recording. At $10 \mathrm{~min}$ after the injection, baseline measurement of respiratory activity was obtained (see previous protocol). The chamber was briefly opened to measure the $T_{b}$. Breathing was monitored under normoxic conditions for an additional $50 \mathrm{~min} . \mathrm{T}_{\mathrm{b}}$ was measured at the end of the experiment. In this series, apnea frequency was calculated at $60 \mathrm{~min}$ after injection; apneic events were counted between minutes 40 and 60 after injection.

Fictive breathing measurements in vitro

After anesthesia and decerebration, the medulla and rostral spinal cord were dissected from pups ( $\mathrm{P} 0-\mathrm{P} 4)$. Using cranial nerves and blood ves-

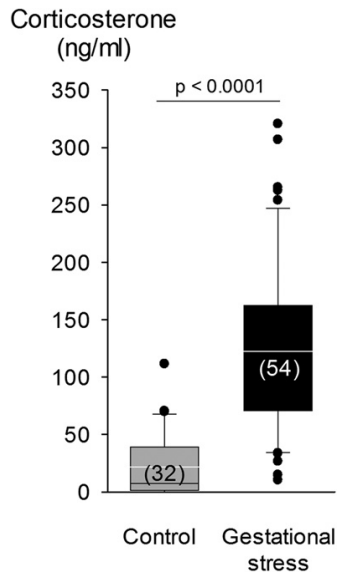

Figure 1. Box plot of the plasma corticosterone levels measured in gestating dams maintained under standard animal care conditions (control; gray bars; $n=32$ ) and females subjected to GS (black bars; $n=54$ ). Tail blood samples were taken at 9:20 A.M. on G12. Box boundaries correspond to the 25 th and 75 th percentiles (top and bottom, respectively); the line within the box indicates the median. Bars above and below show the 90 th and 10th percentiles, respectively. Individual points are outside these limits.

sels of the ventral brainstem as landmarks (Ruangkittisakul et al., 2007), the rostral brainstem was sectioned at the level of cranial nerve VI and the caudal cerebral artery and placed ventral side up in a recording chamber irrigated $(5 \mathrm{ml} / \mathrm{min}$ ) with artificial CSF ( $\mathrm{aCSF}$ ) containing the following (in mM): $129 \mathrm{NaCl}, 3.35 \mathrm{KCl}, 1.15 \mathrm{MgCl}_{2}, 30$ D-glucose, $21 \mathrm{NaHCO}_{3}, 1.26$ $\mathrm{CaCl}_{2}$, and $0.58 \mathrm{NaH}_{2} \mathrm{PO}_{4}$. The superfusate was maintained at $26^{\circ} \mathrm{C}$ and equilibrated with a $95 \% \mathrm{O}_{2} / 5 \% \mathrm{CO}_{2}$ gas mixture, $\mathrm{pH} 7.4 \pm 0.1$. Bursts of inspiratory (phrenic)-related motor activity were recorded extracellularly from the $\mathrm{C} 3$ or $\mathrm{C} 4$ nerve rootlet using a suction electrode. The signal was processed using standard methods (Khemiri et al., 2012).

Protocol and data analyses. The preparation was allowed to stabilize for 20-30 min, until stable rhythmic neural activity was recorded. Baseline recording was then performed for $5 \mathrm{~min}$, and then the effect of 5-HT supplementation on fictive $f_{\mathrm{R}}$ and respiratory variability was assessed by superfusing the preparation with aCSF containing 5-HT ( $5 \mu \mathrm{m}$; SigmaAldrich) for $20 \mathrm{~min}$. The choice of this concentration was based on results from preliminary experiments and recent literature (Voituron et al., 2010). Variability of the "core" respiratory motor output was assessed by calculating the coefficient of variation $(\mathrm{CV})$ of the interburst interval $(\mathrm{CV}=\mathrm{SD} /$ mean $\times 100)$ during $5 \mathrm{~min}$ of baseline recording. 
A

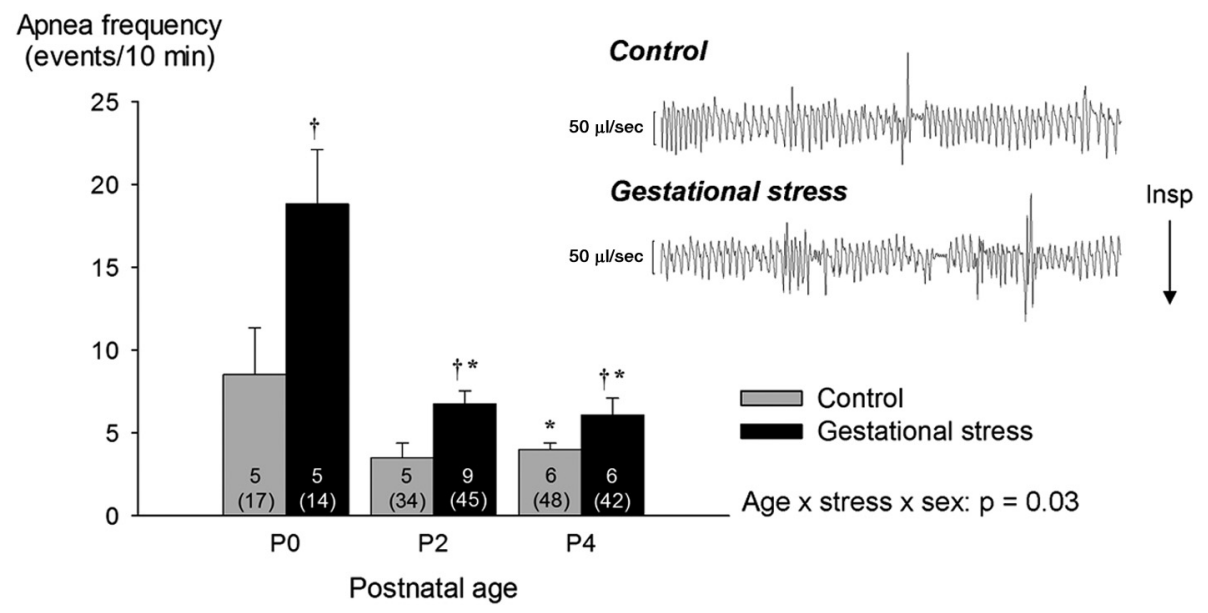

\section{Postnatal day 4}

B

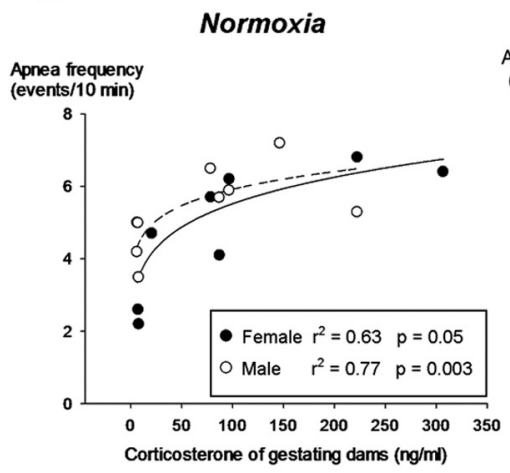

C

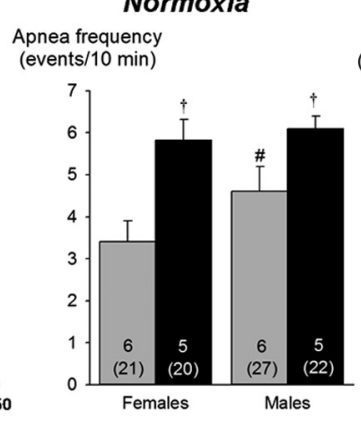

D

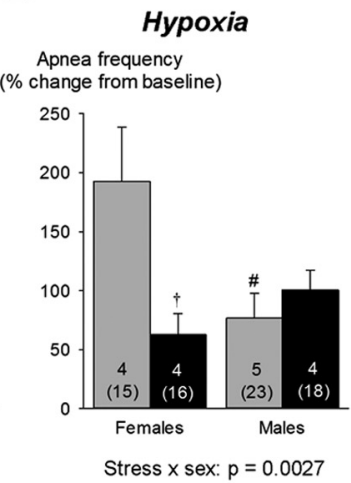

Figure 2. A, Effects of GS on apnea frequency during neonatal development (P0-P4); the right side of the panel presents 30 s segments of plethysmographic recordings illustrating respiratory instability and apneas in newborn pups (P0) born from control (top trace) and stressed (bottom trace) dams. Apnea frequency is the sum of spontaneous and post-sigh apneas measured during baseline recording (normoxia). Because sex-specific differences were apparent only at $\mathrm{P} 4$, the bottom panels present data from males and females separately. $\boldsymbol{B}$, Relationships between maternal corticosterone measured on G12 and mean apnea frequency measured at P4 for each litter. Data for males and females are represented by open and filled circles, respectively. $\boldsymbol{C}$, Apnea frequency measured in 4-d-old male and female pups under normoxic conditions. D. Apnea frequency observed at the end of hypoxic exposure. Values are expressed as means \pm SEM. Note that the mean values are based on litter means. These data were obtained from a total of 200 pups ( 99 controls and $101 \mathrm{stress)}$ ) originating from 27 litters ( 12 controls and 15 stress). In the figure, the numbers within bars indicate the number of litters used in each group, the number underneath (in brackets) indicate the total number of pups sampled. Gray bars, Controls; black bars, GS. ${ }^{*} p<0.05$, statistically different from corresponding value measured in newborn ( $\mathrm{PO},<18 \mathrm{~h}$ old). ${ }^{\dagger} p<0.05$, statistically different from control value. ${ }^{*} p<0.05$, statistically different from corresponding female value.

Measurement of medullary monoamines by HPLC

Tissue preparation. After anesthesia, the medullary region corresponding to the one used for electrophysiological recording was excised from the animal and stored at $-80^{\circ} \mathrm{C}$. On the day of the analysis, each sample was thawed, weighted, and placed in $150 \mu \mathrm{l}$ of methanol before being homogenized with a motorized pestle. The homogenate was then centrifuged at $12,000 \mathrm{rpm}$ at $4^{\circ} \mathrm{C}$ for $15 \mathrm{~min}$. The supernatant was filtered (pore size, $0.45 \mu \mathrm{m})$ and stored at $-80^{\circ} \mathrm{C}$ until measurement by HPLC.

Monoamine analyses. Before injection, $50 \mu \mathrm{l}$ of internal standard (3,4dihydroxybenzalamine hydrobromide) and $50 \mu$ of distilled $\mathrm{H}_{2} 0$ were added to $50 \mu \mathrm{l}$ of supernatant. One hundred microliters of this mixture were then injected with a Hamilton syringe into an HPLC apparatus consisting of a Varian ProStar 410 solvent delivery system (Varian Chromatography Systems) connected to a Decade II electrochemical detector containing a VT-03 electrochemical flow cell (both from Antec Leyden). Concentrations of noradrenaline (NA) and 5-HT were calculated relative to standards of known concentration and corrected for the known concentration of internal standard added to each sample. Each sample concentration was corrected for its initial dilution with methanol and medullary weight and expressed as nanomoles per gram.
Statistics

A mixed ANOVA model (mixed-effect model) was used to study the fixed effect of GS, age, and sex on selected variables of interest. The mixed procedure was used with litter nested within "gestational stress" as a random factor to take into account the correlation within animals from the same litter and thus ensure that between-group differences were not attributable to a litter effect. Several studies have discussed the advantages of this approach in developmental studies using multiparous species (Zorrilla, 1997; Wainwright et al., 2007). When ANOVA results indicated that a factor (or interaction between factors) was significant ( $p \leq 0.05$ ), the analysis was followed by Fisher's post hoc test, whenever appropriate. $p$ values for ANOVA results are reported in the figures; results from post hoc tests are indicated by symbols in the figures. The number of litters in each group is indicated within the bars of the histograms; the total number of pups in each group is reported in parentheses. The relationship between maternal corticosterone and apnea frequency (see Fig. 2C) was analyzed using the least-square method. Analyses were performed using JMP (version 10; SAS Institute). Data are reported as mean \pm 1 SEM. Note that mean values reported in the text, Table 1 , and figures are based on litter means (i.e., a mean value was obtained for each litter, and these values were then averaged). 
A

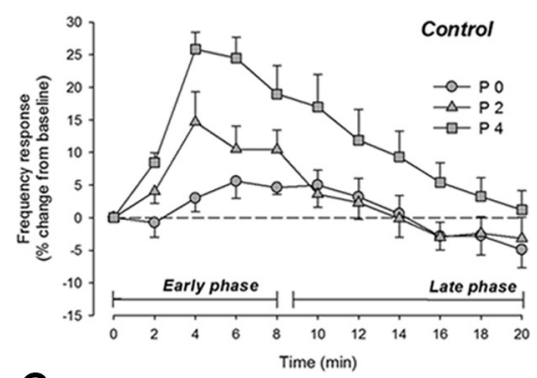

C

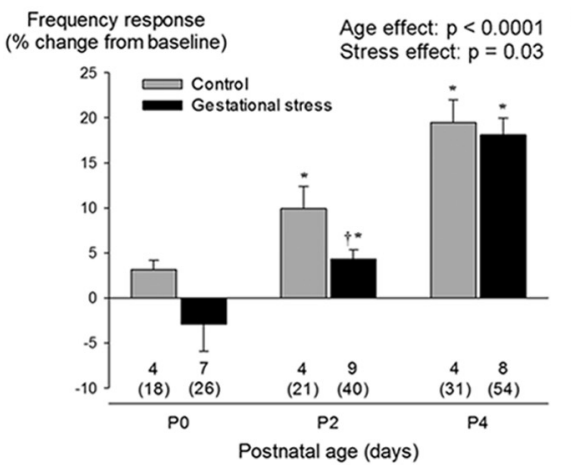

E

$\mathrm{O}_{2}$ consumption response

(\% change from baseline)

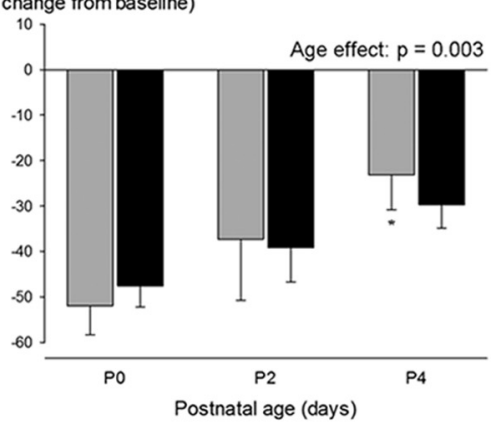

Figure 3. Neonatal development of the ventilatory response to hypoxia in pups born to control dams (gray) versus pups born to dams subjected to GS (black). Time course of the $f_{R}$ response to hypoxia in three distinct age groups: $\mathrm{PO}$ (circles), $\mathrm{P} 2$ (triangles), and P4 (squares). This representation illustrates the early (first $8 \mathrm{~min}$ ) and late phases (minutes 9 to 20) of the response. Results are compared between control pups ( $\boldsymbol{A}$; gray) and pups born to dams subjected to $G S$ ( $\boldsymbol{B}$; black). $\boldsymbol{C}$, Comparison of the mean frequency response observed during the early phase of hypoxia. Effects of $G S$ on $\dot{V}_{E}(D)$ and $\dot{V}_{2}(E)$ responses measured at the end of hypoxic exposure (late phase). Ventilatory measurements were performed using whole-body, flow-through plethysmography during exposure to moderate hypoxia ( $\mathrm{FiO}_{2}=0.12 ; 20 \mathrm{~min}$ ). Values are expressed as percentage change from baseline values and are reported as means \pm SEM. Note that mean values are based on litter means. These data were obtained from a total of 190 pups (70 controls and 120 stress) originating from 22 litters ( 7 controls and 15 stress). Numbers below the bars $(\boldsymbol{C})$ indicate the number of litters used in each group, the number underneath (in parentheses) indicates the total number of pups sampled. ${ }^{*} p<0.05$, statistically different from $\mathrm{PO} .{ }^{\dagger} p<0.05$, statistically different from control value.

\section{Results}

Stress protocol augments plasma corticosterone levels in gestating dams

On G12, plasma corticosterone levels measured in dams immediately after the fourth stress exposure were higher than controls (Fig. 1). The weight gain during gestation did not differ between groups ( $p=0.47$; data not shown).

\section{GS increases apnea frequency in newborn pups}

Baseline data from male and female pups were pooled because, except for body weight (Table 1) and apnea frequency (P4; Fig. $2 B)$, ANOVAs revealed no sex-specific effect on any of the pa- rameters studied. At birth, the $\mathrm{V}_{\mathrm{T}}$ of GS pups was slightly higher than controls; this result contributes to the higher $\dot{\mathrm{V}} \mathrm{E}$ and relative hyperventilation (convective ratio) observed in this group (Table 1). The apnea frequency decreased progressively with age but was consistently higher in pups subjected to GS than controls (Fig. 2). At P4, the mean apnea frequency calculated for each litter correlated positively with the corticosterone levels measured in the mother during gestation (Fig. $2 B)$; apneas were more frequent in males than females (Fig. 2C). The increase in apnea frequency was mainly attributable to an increase in post-sigh apneas; GS did not affect apnea duration (stress effect, $p=0.22$; data not shown). Exposure to hypoxia augmented apnea frequency, especially in female pups born to control dams (Fig. 2D). Hypercapnia had no effect on this variable $(p=0.1$; data not shown).

\section{GS delays maturation of the HVR}

In most pups, $f_{\mathrm{R}}$ began to increase within the first 2 min of hypoxia (Fig. $3 A, B$ ). The hyperpnea observed during the early phase of hypoxia increased with age but was lower in GS pups than controls (Fig. 3C). Unlike controls, GS pups did not display a significant hyperventilation until P2. The HVR of newborns being biphasic (Fig. $3 A, B$ ), the VE measured during the last $4 \mathrm{~min}$ of hypoxia was not above baseline. The $\dot{V}$ E response did not change over the first $4 \mathrm{~d}$ of life and was not influenced by GS (Fig. 3D). Of note, the VE response of female pups was slightly less than males; this difference was most noticeable in 2-d-old stressed pups. Conversely, the decrease in $\dot{\mathrm{VO}}_{2}$ that takes place during hypoxia in newborn diminished progressively with age but did not differ between groups or sexes (Fig. 3E).

\section{GS reduces medullary 5-HT and NA levels in newborn pups}

Medullary 5-HT levels changed with age; however, the maturation pattern differed between control and GS pups (Fig. 4A). At birth, medullary 5-HT levels of GS pups was 32\% lower than controls. Medullary NA levels did not change with age but were lower in GS pups than controls (Fig. 4B).

\section{GS reduces regularity of core medullary networks generating} respiratory motor output

Basal phrenic burst frequency augmented with age (Fig. 5A). At P4, however, fictive $f_{\mathrm{R}}$ of GS males was $31 \%$ lower than controls; this effect was not observed in females (Fig. $5 B$ ). The agedependent increase in motor output concurred with a progressive reduction in the $\mathrm{CV}$ of the interburst interval (Fig. 5C). However, the variability inherent to medullary preparations from 


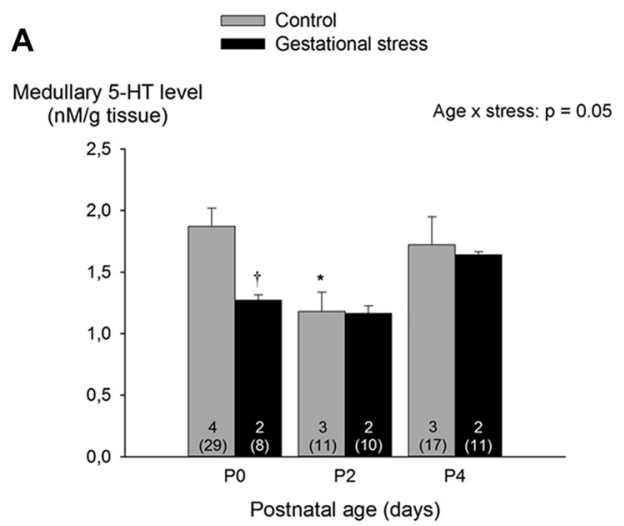

B

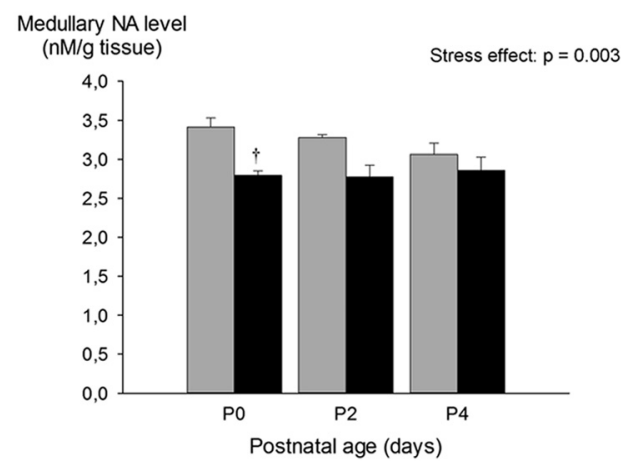

Figure 4. Effects of $G S$ on medullary levels of $5-H T(A)$ and $N A(B)$ in developing newborn rat pups. Measurements were performed by HPLC. Gray bars, Controls; black bars, GS. Values are expressed as means $\pm S E M$. Note that mean values are based on litter means. These data were obtained from a total of 86 pups (57 controls and 29 stress) originating from nine litters (7 controls and 2 stress). Numbers within the bars $(\boldsymbol{A})$ indicate the number of litters used in each group, and the number underneath (in parentheses) indicate the total number of medullas sampled. ${ }^{*} p<0.05$, statistically different from $\mathrm{P} 0 .{ }^{\dagger} p<0.05$, statistically different from corresponding control value.

GS pups was greater than controls (Fig. 5C). This effect was not sex dependent.

\section{The pathological consequences of GS are significant at P4}

At P4, corticosterone levels of male pups born to stressed dams were higher than controls (Fig. 6A). Conversely, their testosterone levels were reduced substantially (Fig. 6B). The hypercapnic ventilatory response of female GS pups was $17 \%$ higher than controls (Fig. 7); this sex-specific effect was mainly mediated by an increased $\mathrm{V}_{\mathrm{T}}$ response (Fig. $7 \mathrm{C}$ ). Desaturations and bradycardias were mostly observed after spontaneous apneas. The proportion of apneas with $\mathrm{O}_{2}$ desaturation was higher in stressed pups than controls (Fig. $8 A, B$ ). Baseline $\mathrm{SpO}_{2}$ did not differ between groups $(98.4 \pm 0.4$ vs $98.8 \pm 0.1 \%$ for control and GS, respectively). During desaturating apneas, $\mathrm{SpO}_{2}$ decreased on average by $11 \pm 1 \%$; this value did not differ between groups (Fig. $8 C$ ). The proportion of apneas with bradycardias was not influenced by GS (Fig. $8 B$ ). During those events, the average decrease in heart rate was $9.2 \pm 1.0 \%$.

\section{5-HT-based treatment alleviates the consequences of} stress-induced respiratory instability

Addition of 5-HT ( $5 \mu \mathrm{M})$ to the superfusion medium reduced the CV of the interburst interval; this "stabilizing" effect was greater in preparations from GS pups (Fig. 9A). These effects were not related to an increase in phrenic burst frequency (Fig. 9B,C). In

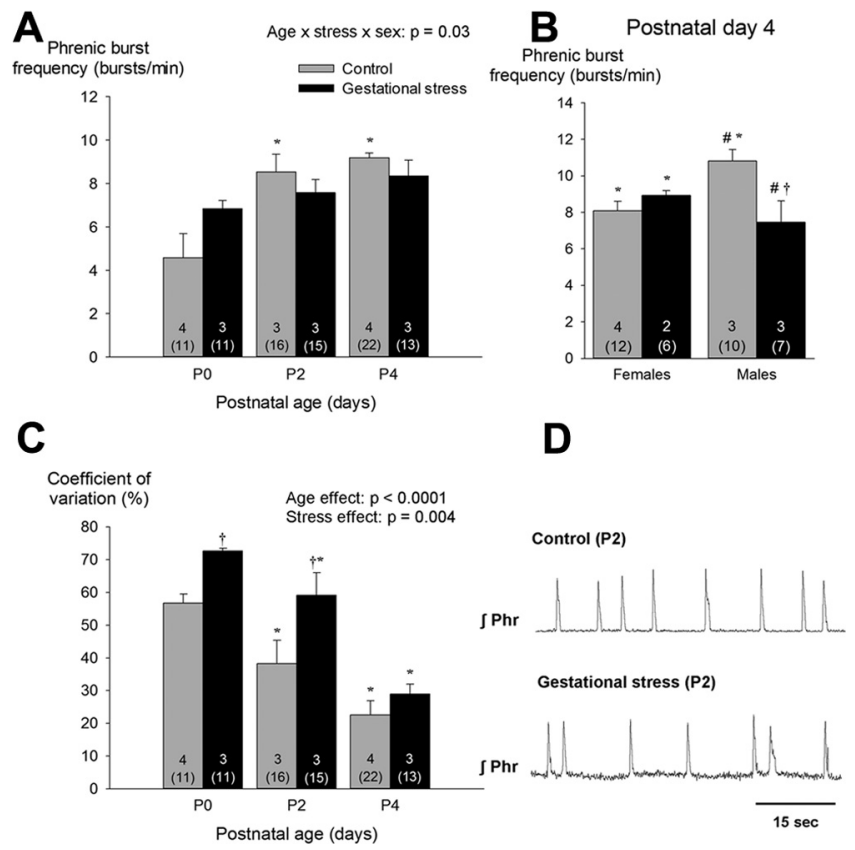

Figure 5. $A$, Effects of GS on age-dependent changes in basal phrenic burst frequency produced by in vitro medullary preparations. Because sex-specific differences were apparent only at $P 4, B$ presents data from males and females separately. $\boldsymbol{C}$, Developmental change of the $C V$ of the interburst interval between pups born from control dams (gray bars) versus dams subjected to GS (black bars). D, Phrenic neurograms (integrated signal) from 2-d-old pups illustrating differences in variability observed between preparations from stressed and control pups. Values are expressed as means \pm SEM. Note that mean values are based on litter means. These data were obtained from a total of 88 pups ( 49 controls and 39 stress) originating from 14 litters ( 9 controls and 5 stress). In each panel, the numbers within the bars indicate the number of litters used in each group; the number underneath (in parentheses) indicate the total number of preparations used. ${ }^{*} p<0.05$, statistically different from $\mathrm{PO}$ ( $<18 \mathrm{~h}$ old). ${ }^{\dagger} p<0.05$, statistically different from corresponding control value. ${ }^{\#} p<0.05$, statistically different from corresponding female value.

GS pups, the frequency response to 5-HT application differed between males and females (Fig. 9B, C). In intact pups, intraperitoneal injection of the selective $5-\mathrm{HT}_{1 \mathrm{~A}}$ receptor agonist $8-\mathrm{OH}$ DPAT reduced the apnea frequency; the effect was greatest in pups born to stressed dams (Fig. 10A). Compared with salineinjected pups, 8-OH-DPAT did not increase $f_{\mathrm{R}}, \dot{\mathrm{V}} \mathrm{E}, \dot{\mathrm{V}} \mathrm{O}_{2}$, or $\mathrm{T}_{\mathrm{b}}$ (data not shown). At $\mathrm{P} 4,8-\mathrm{OH}-\mathrm{DPAT}$ treatment reduced the fraction of apneas with $\mathrm{O}_{2}$ desaturation; this effect was greater in male pups (Fig. 10B). 8-OH-DPAT also reduced the proportion of apneas with bradycardias in males but not females (Fig. 10C).

\section{Discussion}

Maternal socioeconomic status, malnutrition, and substance abuse interfere with brain development and are established risk factors for respiratory disorders and SIDS in infants (Darnall et al., 2006; Calhoun et al., 2010; Duncan et al., 2010). However, the nature, diversity, and complex interactions among these stressful situations for the gestating mother have made it difficult to identify a mechanism accounting for the deleterious consequences of poor fetal conditions on breathing at birth. Here, we demonstrate that GS alone is sufficient to disrupt respiratory regulation and promote apneic events with significant physiological consequences in rat pups; many of these effects are more important in males. We therefore propose that repeated activation of the neuroendocrine response to stress in the gestating mother is a key factor in the etiology of respiratory disorders in newborn. 
A

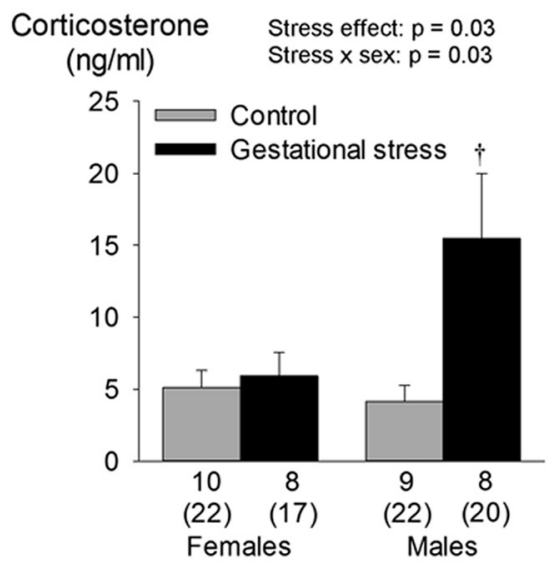

B

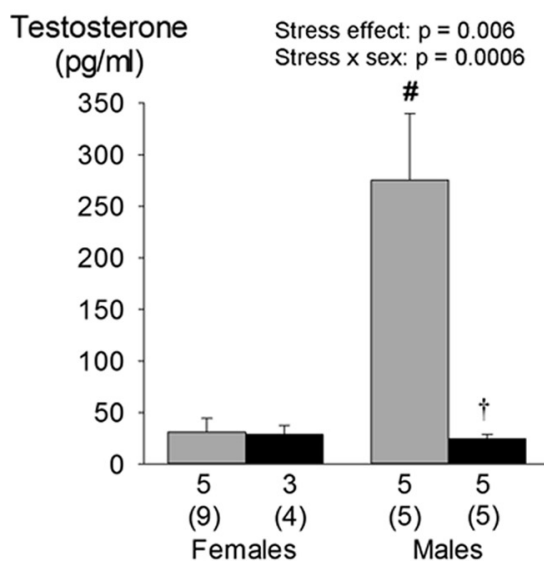

Figure 6. Effects of GS on circulating levels of corticosterone $(\boldsymbol{A})$ and testosterone $(\boldsymbol{B})$ in 4-d-old male and female pups. Values are expressed as means \pm SEM, which are based on litter averages. These data were obtained from a total of 104 pups (58 controls and 46 stress) originating from 31 litters (16 controls and 15 stress). In each panel, the numbers underneath the bars indicate the number of litters sampled in each group; the numbers immediately below (in brackets) indicate the total number of pups used in this group. ${ }^{\dagger} p<0.05$ statistically different from corresponding control value. ${ }^{\#} p<0.05$, statistically different from corresponding female value.

\section{Mechanisms by which GS promotes respiratory instability} and apneas in newborn pups

Compared with humans, the CNS of pups born at term is immature (Clancy et al., 2001). This relative immaturity, combined with incomplete chemoreflex maturation at birth, make the newborn rat an excellent model to investigate respiratory control development and the factors influencing its trajectory. The progressive decline in both apnea frequency (in vivo) and rhythm variability (in vitro) observed after birth illustrate the maturation of the respiratory control system in this species. The fact that both variables were consistently greater in pups born to GS dams demonstrates that development of the neural circuits that regulate breathing is vulnerable to the hormonal changes induced by our stress protocol. The correlations between maternal corticosterone and apnea frequency at $\mathrm{P} 4$ support this interpretation. Furthermore, data showing that, at $\mathrm{P} 4$, the proportion of apneas with $\mathrm{O}_{2}$ desaturations is greater in GS pups than controls indicate that GS also affects cardio-respiratory coupling and that the physiological consequences of apneas are more important in stressed pups. The diverse experimental approaches used pro-
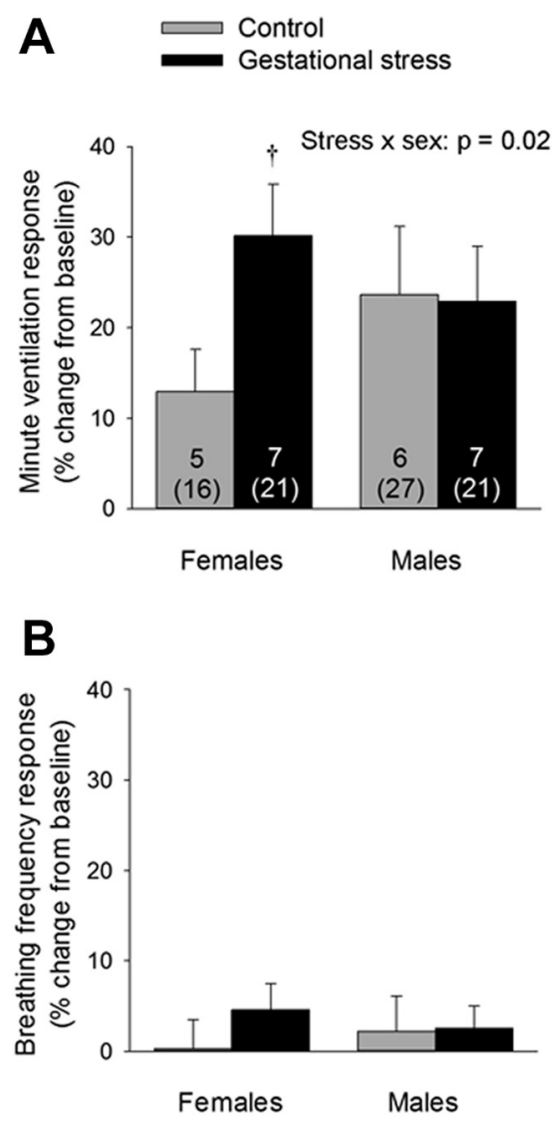

C

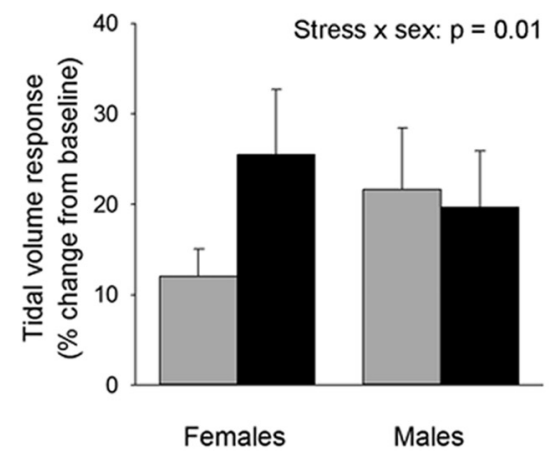

Figure 7. $A$, Comparison of the $\dot{V}_{E}$ response to moderate hypercapnia $\left(\mathrm{FiCO}_{2}=0.05 ; 20 \mathrm{~min}\right)$ between pups born to control dams (gray bars) versus pups born to dams subjected to $\mathrm{GS}$ (black bars). $f_{R}(B)$ and $V_{T}(C)$ components of the response. Data were obtained over the last 5 min of hypercapnia and are expressed as a percentage change from baseline. Values are expressed as means \pm SEM based on litter averages. These data were obtained from a total of 85 pups (43 controls and 42 stress) originating from 13 litters ( 6 controls and 7 stress). In $A$, the numbers within the bars indicate the number of litters sampled in each group; the numbers below (in parentheses) indicate the total number of pups used in this group. ${ }^{\dagger} p<0.05$, statistically different from corresponding control value.

vide insight into the mechanisms contributing to this pathological phenotype.

The HVR increases during early life (Rigatto, 1992; Bissonnette, 2000). This maturation was observed in our experiments; however, the HVR of GS pups was lower than controls (especially at $\mathrm{P} 0$ and $\mathrm{P} 2$ ). This result is significant because $\mathrm{O}_{2}$ responsiveness is an important defense system against hypoxia and disruption of this reflex by GS may be threatening to the newborn (Leiter and Böhm, 2007; Kinney, 2009). Although it is interesting that this 
effect of GS is similar to the effects of prenatal nicotine (Huang et al., 2010) and cocaine (Moss et al., 1995; Lipton et al., 1996), it is unlikely that the reduced HVR alone explains the higher apnea frequency that characterized GS pups. In rat pups, the incidence of apneas correlates positively with the magnitude of the HVR (Julien et al., 2008). In preterm infants, an augmented (rather than reduced) $\mathrm{O}_{2}$ chemoreflex, as indicated by the rapid change in breathing that occurs during exposure to moderate hypoxia or hyperoxia, exacerbates periodic breathing and promotes apneas (Al-Matary et al., 2004; Gauda et al., 2004). Conversely, a reduced ventilatory response to $\mathrm{CO}_{2}$ contributes to respiratory disorders in the newborn, such as apnea of prematurity (KatzSalamon, 2004; Gaultier and Gallego, 2005), and is a risk factor for SIDS (Gauda et al., 2004; Kinney et al., 2009). Here, GS augmented the ventilatory response to $\mathrm{CO}_{2}$ observed at P4 in females only. Although limited, this sex-specific effect is consistent with the persistent enhancement of the hypercapnic ventilatory response that emerges after neonatal stress (Genest et al., 2007). However, it does not explain why GS pups (especially males) produced more apneas than controls during normoxia.

In mammals, the rhythmic motor command driving lung ventilation emerges during fetal life. Because the frequency and the stability of the motor output produced by medullary preparations from newborn rodents and fetuses increases progressively with age, immaturity and/or deficiency in rhythmogenic mechanisms has been linked to respiratory instability and apneas in preterm infants (Hilaire and Duron, 1999; Gaultier and Gallego, 2005; Greer et al., 2006). Here, the instability measured in preparations from GS pups was larger than controls, and the frequency measured at P4 was lower in male GS pups than controls. Thus, disruption of development and function of the core networks generating and modulating respiratory rhythm likely contribute to the increased propensity for pathological apneas observed in GS pups. Results from 5-HT-based "treatment" support this interpretation.

\section{Stress-induced 5-HT deficit and respiratory instability in newborn}

During gestation, activation of glucocorticoid receptors has ageand region-specific effects on brain monoaminergic systems of pups (Peters, 1982; Muneoka et al., 1997). Administration of dexamethasone to gestating dams augments expression of the presynaptic 5-HT transporter in 14-d-old pups, thus reducing 5-HT levels in the synaptic cleft (Slotkin et al., 1996). Tryptophan hydroxylase regulates 5-HT synthesis, and, in rats, its activity is greatly influenced by corticosterone such that adverse conditions exert region- and stress-specific effects on the central serotonergic system (Chaouloff, 2000). Although acute stress augments tryptophan hydroxylase activity (Azmitia and McEwen, 1974), chronic stress reduces the number of 5-HT neurons and terminals (Kitayama et al., 1989). Moreover, GS persistently reduces tyrosine hydroxylase mRNA expression in noradrenergic neurons in the dorsal pons (Green et al., 2011). Our results demonstrate that GS results in medullary 5-HT and NA deficiency in newborns. Although this effect did not persist beyond birth (P0), transient reduction in medullary monoamines by GS (especially 5-HT) may be sufficient to affect respiratory control development. In addition to its prominent role in autonomic regulation, 5-HT also exerts neurotrophic influence on neural circuit development during the prenatal and postnatal periods (Hodges and Richerson, 2008; Hilaire et al., 2010). Consistent with this crucial role, reduction/elimination of 5-HT and NA neurons in rodents causes important respiratory disorders, including respiratory instability and apneas (Viemari et al., 2005; Hodges et al., 2008; Hilaire et al., 2010). In humans, brainstem 5-HT and NA deficiency are associated with SIDS (Paterson et al., 2009; Duncan et al., 2010). Several risk factors have been evoked to explain these effects, but the nature of the mechanisms leading to monoamine deficiency (and related respiratory disorders) remain unknown (Kinney and Thach, 2009). The present results allow us to propose that elevation of corticosterone (cortisol in humans) during pregnancy contributes to medullary 5-HT and NA deficiency in newborns. Although both monoamines could be important, we chose to focus on the 5-HT system because of the following: (1) 
A

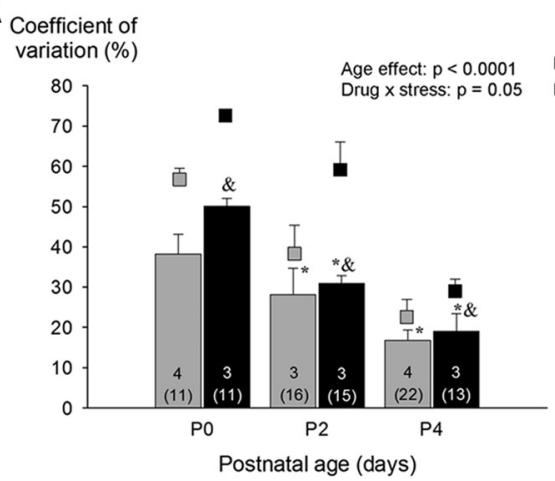

B

Burst frequency response (\% baseline)
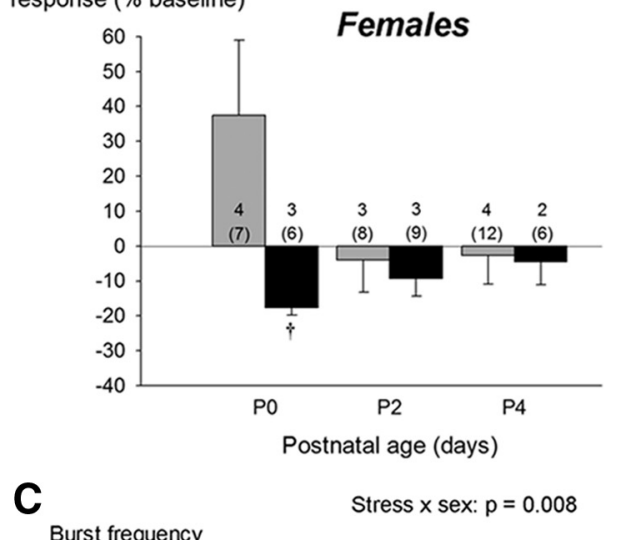

Burst frequency response (\% baseline)

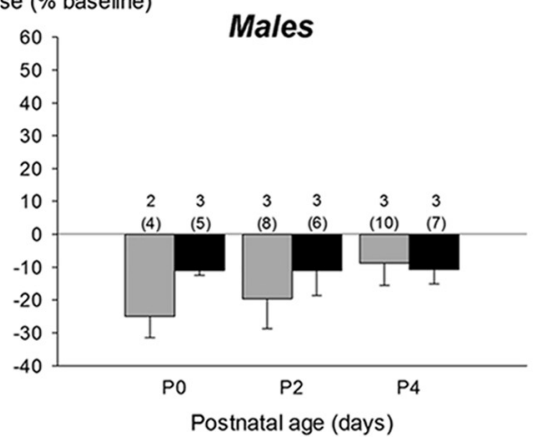

Figure 9. Effects of 5-HT (5 $\mu \mathrm{M})$ bath application on inspiratory (phrenic) motor output produced by medullary preparation during the neonatal period ( $\mathrm{PO}-\mathrm{P} 4)$. Results are compared between preparations from pups born from control dams (gray bars) and pups born from females subjected to stress during gestation (black bars). $A, 5$ - $\mathrm{HT}$ reduces the $\mathrm{CV}$ of the interburst interval; data from untreated (aCSF) preparations is presented with squares to facilitate comparison. The change in burst frequency after 5 -HT application is presented separately for females $(\boldsymbol{B})$ and males $(\boldsymbol{C})$. These data are reported as a percentage change from baseline (pre-5$\mathrm{HT})$. Values are expressed as means \pm SEM based on litter averages. These results were obtained from a total of 88 pups ( 49 controls and 39 stress) originating from 14 litters ( 9 controls and 5 stress). In each panel, the numbers within the bars indicate the number of litters sampled in each group; the numbers below (in parentheses) indicate the total number of pups used in this group. ${ }^{*} p<0.05$, statistically different from PO ( $<18$ h old). ${ }^{\&} p<0.05$, statistically different from corresponding aCSF (untreated) value.

5-HT agonists (especially 5- $\mathrm{HT}_{1 \mathrm{~A}}$ ) are highly effective in stabilizing breathing in both animals and humans (Richter et al., 2003; Dutschmann et al., 2009; Manzke et al., 2009); (2) 5- $\mathrm{HT}_{1 \mathrm{~A}}$ receptors are the most extensively expressed subtype within the central respiratory network (Richter et al., 2003); (3) 5- $\mathrm{HT}_{1 \mathrm{~A}}$ receptors are greatly reduced in the brainstem of SIDS victims (Ozawa and Okado, 2002; Kinney et al., 2009; Duncan et al., 2010); and (4) the
A

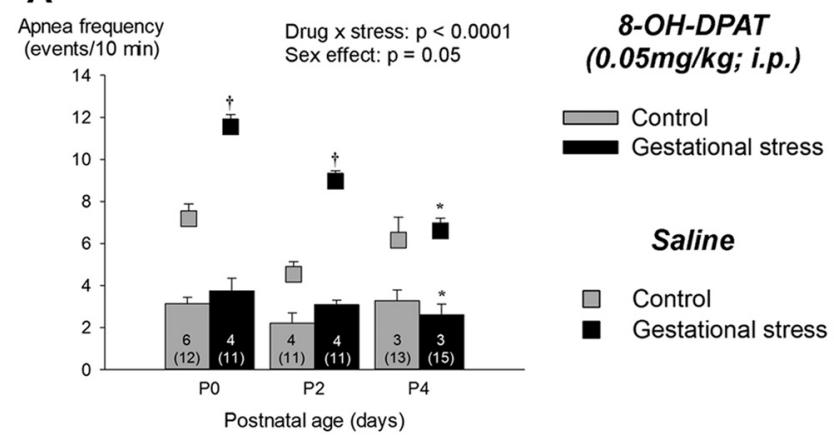

Postnatal day 4
B

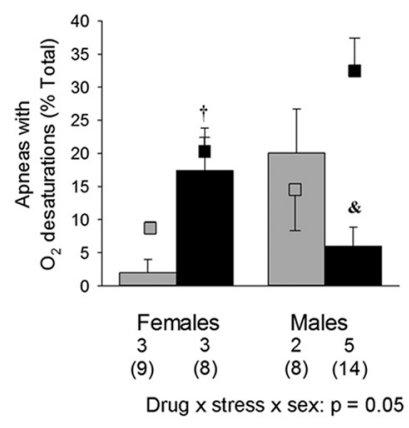

C
Figure 10. $\boldsymbol{A}$, Effects of acute administration of the selective $5-\mathrm{HT}_{1 \mathrm{~A}}$ agonist 8-OH-DPAT $(0.05 \mathrm{mg} / \mathrm{kg}$, i.p.) on apnea frequency in developing newborn pups (PO-P4). The effects are compared between pups born to control dams (gray bars) versus pups born to dams subjected to GS (black bars). Measurements were taken 60 min after the injection. The physiological consequences of this treatment were evaluated on $\mathrm{P} 4$ with pulse oxymetry to measuring the proportion of apneas with desaturations $(\boldsymbol{B})$ or bradycardias $(\boldsymbol{C})$. Because sex-specific effects were significant, males and females are presented separately. Values obtained after saline injection (sham) are reported with square symbols for comparison. Results are expressed as means \pm SEM; means are based on litter averages. These data were obtained from a total of 184 pups ( 89 controls and 95 stress) originating from 27 litters (14 controls and 13 stress). The numbers within the bars $(\boldsymbol{A}, \boldsymbol{C})$ indicate the number of litters sampled in each group; the numbers below (in parentheses) indicate the total number of pups used in this group. ${ }^{*} p<0.05$, statistically different from $\mathrm{PO}$ ( $<18 \mathrm{~h}$ old). ${ }^{\dagger} p<0.05$, statistically different from corresponding control value. ${ }^{\&} p<0.05$, statistically different from corresponding saline value.

male/female difference in $5-\mathrm{HT}_{1 \mathrm{~A}}$ receptors may explain the increased risk of SIDS in males versus females (Kinney et al., 2009).

The increase in respiratory rhythm stability following 5-HT bath application (in vitro) along with the reduction of apneas following 8-OH-DPAT injection (in vivo) support an important role for 5-HT. These results and the fact that the effects of 5-HT agents were greater in GS pups indicate that a deficit in medullary 5-HT contributes to respiratory disorders in GS newborn. Considering that the prevalence of many respiratory disorders (including SIDS) is greater in males (Mage and Donner, 2006) and the reduction in $5-\mathrm{HT}_{1 \mathrm{~A}}$ receptor binding observed in SIDS victims is greater in males than females (Kinney et al., 2009), it is interesting that reduction of apneic events with $\mathrm{O}_{2}$ desaturations by $8-\mathrm{OH}$-DPAT administration was significant only in male pups that experienced GS. In adult rodents, the expression of 5- $\mathrm{HT}_{1 \mathrm{~A}}$ receptors is reduced by corticosteroids and augmented by testosterone (Chalmers et al., 1993; Flügge et al., 1998). Stress generally interferes with androgen secretion and GS reduces testosterone levels in male offspring (Weisz and Ward, 1980; Kapoor and Matthews, 2005). The endocrine profile observed in $4 \mathrm{~d}$ old pups is consistent with these reports; the sex- and stress specific cardio- 
respiratory responses to 8-OH-DPAT injection further support the notion that the balance between glucocorticoids and androgen is a key determinant of the behaviors modulated by $5-\mathrm{HT}_{1 \mathrm{~A}}$ receptors.

\section{Perspectives}

Factors underlying respiratory disorders of newborns are numerous. Unlike research in human subjects, the rat allows better control over the nature, intensity, and duration of the stress paradigm while eliminating confounding factors such as maternal life style. Though the increase in corticosterone induced by our stress paradigm was relatively modest, repeated exposure to this protocol was sufficient to augment apneic events and respiratory instability in newborn rats. Non-invasive measurement of $\mathrm{SpO}_{2}$ and heart rate at $\mathrm{P} 4$ showed that these apneas are physiologically significant and with time, could compromise brain development (Baird, 2004; Talge et al., 2007; Zhao et al., 2011). Animal models have inherent limitations. Stress has broad effects on the mother and the pups and the deleterious consequences of chronic corticosterone elevation on development were not limited to breathing in pups. Nevertheless, the significant impact that GS exerts on the development of respiratory control still raises important questions and point to new factors in the etiology of respiratory disorders of newborns. Such novel findings are essential to the development of prevention strategies and interventions. In that regard, the efficiency of 5-HT agonists in alleviating instability and apneas suggest that these agents may have therapeutic potential in this vulnerable population.

\section{References}

Al-Matary A, Kutbi I, Qurashi M, Khalil M, Alvaro R, Kwiatkowski K, Cates D, Rigatto H (2004) Increased peripheral chemoreceptor activity may be critical in destabilizing breathing in neonates. Semin Perinatol 28:264272. CrossRef Medline

Azmitia EC Jr, McEwen BS (1974) Adrenalcortical influence on rat brain tryptophan hydroxylase activity. Brain Res 78:291-302. CrossRef Medline

Bairam A, Niane LM, Joseph V (2012) Role of ATP and adenosine on carotid body function during development. Respir Physiol Neurobiol. Advance online publication. Retrieved November 28, 2012. doi: 10.1016/j.resp.2012.06.016. CrossRef Medline

Baird TM (2004) Clinical correlates, natural history and outcome of neonatal apnoea. Semin Neonatol 9:205-211. CrossRef Medline

Bissonnette JM (2000) Mechanisms regulating hypoxic respiratory depression during fetal and postnatal life. Am J Physiol Regul Integr Comp Physiol 278:R1391-R1400. Medline

Calhoun SL, Vgontzas AN, Mayes SD, Tsaoussoglou M, Sauder K, Mahr F, Karippot A, Wisner K, Bixler EO (2010) Prenatal and perinatal complications: is it the link between race and SES and childhood sleep disordered breathing? J Clin Sleep Med 6:264-269. Medline

Chalmers DT, Kwak SP, Mansour A, Akil H, Watson SJ (1993) Corticosteroids regulate brain hippocampal 5-HT1A receptor mRNA expression. J Neurosci 13:914-923. Medline

Chandramohan Y, Droste SK, Reul JM (2007) Novelty stress induces phospho-acetylation of histone $\mathrm{H} 3$ in rat dentate gyrus granule neurons through coincident signalling via the $N$-methyl-D-aspartate receptor and the glucocorticoid receptor: relevance for c-fos induction. J Neurochem 101:815-828. CrossRef Medline

Chaouloff F (2000) Serotonin, stress and corticoids. J Psychopharmacol 14: 139-151. CrossRef Medline

Clancy B, Darlington RB, Finlay BL (2001) Translating developmental time across mammalian species. Neuroscience 105:7-17. CrossRef Medline

Damianopoulos EN, Carey RJ (1995) Evidence for N-methyl-aspartate receptor mediation of cocaine induced corticosterone release and cocaine conditioned stimulant effects. Behav Brain Res 68:219-228. CrossRef Medline

Darnall RA, Ariagno RL, Kinney HC (2006) The late preterm infant and the control of breathing, sleep, and brainstem development: a review. Clin Perinatol 33:883-914, abstract x. CrossRef Medline

Drorbaugh JE, Fenn WO (1955) A barometric method for measuring ventilation in newborn infants. Pediatrics 16:81-87. Medline
Duncan JR, Paterson DS, Hoffman JM, Mokler DJ, Borenstein NS, Belliveau RA, Krous HF, Haas EA, Stanley C, Nattie EE, Trachtenberg FL, Kinney HC (2010) Brainstem serotonergic deficiency in sudden infant death syndrome. JAMA 303:430-437. CrossRef Medline

Dutschmann M, Waki H, Manzke T, Simms AE, Pickering AE, Richter DW, Paton JFR (2009) The potency of different serotonergic agonists in counteracting opioid evoked cardiorespiratory disturbances. Philos Trans R Soc B Biol Sci 364:2611-2623. CrossRef Medline

Eichenwald EC, Zupancic JA, Mao WY, Richardson DK, McCormick MC, Escobar GJ (2011) Variation in diagnosis of apnea in moderately preterm infants predicts length of stay. Pediatrics 127:e53-e58. CrossRef Medline

Fendt M, Endres T (2008) 2,3,5-Trimethyl-3-thiazoline (TMT), a component of fox odor-just repugnant or really fear-inducing? Neurosci Biobehav Rev 32:1259-1266. CrossRef Medline

Field T, Diego M (2008) Cortisol: the culprit prenatal stress variable. Int J Neurosci 118:1181. CrossRef Medline

Finer NN, Higgins R, Kattwinkel J, Martin RJ (2006) Summary proceedings from the apnea-of-prematurity group. Pediatrics 117:S47-S51. CrossRef Medline

Flügge G, Kramer M, Rensing S, Fuchs E (1998) $5 \mathrm{HT}_{1 \mathrm{~A}}$-receptors and behaviour under chronic stress: selective counteraction by testosterone. Eur J Neurosci 10:2685-2693. CrossRef Medline

Fournier S, Allard M, Gulemetova R, Joseph V, Kinkead R (2007) Chronic corticosterone elevation and sex-specific augmentation of the hypoxic ventilatory response in awake rats. J Physiol 584:951-962. CrossRef Medline

Fournier S, Joseph V, Kinkead R (2011) Influence of juvenile housing conditions on the ventilatory, thermoregulatory, and endocrine responses to hypoxia of adult male rats. J Appl Physiol 111:516-523. CrossRef Medline

Gauda EB, McLemore GL, Tolosa J, Marston-Nelson J, Kwak D (2004) Maturation of peripheral arterial chemoreceptors in relation to neonatal apnoea. Semin Neonatol 9:181-194. CrossRef Medline

Gaultier C, Gallego J (2005) Development of respiratory control: evolving concepts and perspectives. Respir Physiol Neurobiol 149:3-15. CrossRef Medline

Genest SE, Gulemetova R, Laforest S, Drolet G, Kinkead R (2007) Neonatal maternal separation induces sex-specific augmentation of the hypercapnic ventilatory response in awake rat. J Appl Physiol 102:1416-1421. CrossRef Medline

Green MK, Rani CS, Joshi A, Soto-Piña AE, Martinez PA, Frazer A, Strong R, Morilak DA (2011) Prenatal stress induces long term stress vulnerability, compromising stress response systems in the brain and impairing extinction of conditioned fear after adult stress. Neuroscience 192: 438-451. CrossRef Medline

Greer JJ, Funk GD, Ballanyi K (2006) Preparing for the first breath: prenatal maturation of respiratory neural control. J Physiol 570:437-444. CrossRef Medline

Gulemetova R, Kinkead R (2011) Neonatal stress increases respiratory instability in rat pups. Respir Physiol Neurobiol 176:103-109. CrossRef Medline

Han F, Subramanian S, Price ER, Nadeau J, Strohl KP (2002) Periodic breathing in the mouse. J Appl Physiol 92:1133-1140. CrossRef Medline

Hilaire G, Duron B (1999) Maturation of the mammalian respiratory system. Physiol Rev 79:325-360. Medline

Hilaire G, Voituron N, Menuet C, Ichiyama RM, Subramanian HH, Dutschmann M (2010) The role of serotonin in respiratory function and dysfunction. Respir Physiol Neurobiol 174:76-88. CrossRef Medline

Hodges MR, Richerson GB (2008) Contributions of 5-HT neurons to respiratory control: neuromodulatory and trophic effects. Respir Physiol Neurobiol 164:222-232. CrossRef Medline

Hodges MR, Tattersall GJ, Harris MB, McEvoy SD, Richerson DN, Deneris ES, Johnson RL, Chen ZF, Richerson GB (2008) Defects in breathing and thermoregulation in mice with near-complete absence of central serotonin neurons. J Neurosci 28:2495-2505. CrossRef Medline

Huang YH, Brown AR, Cross SJ, Cruz J, Rice A, Jaiswal S, Fregosi RF (2010) Influence of prenatal nicotine exposure on development of the ventilatory response to hypoxia and hypercapnia in neonatal rats. J Appl Physiol 109:149-158. CrossRef Medline

Hunt CE, Corwin MJ, Weese-Mayer DE, Davidson Ward SL, Ramanathan R, Lister G, Tinsley LR, Heeren T, Rybin D; Collaborative Home Infant Monitoring Evaluation (CHIME) Study Group (2011) Longitudinal as- 
sessment of hemoglobin oxygen saturation in preterm and term infants in the first six months of life. J Pediatrics 159:377-383.el. CrossRef Medline

Julien C, Bairam A, Joseph V (2008) Chronic intermittent hypoxia reduces ventilatory long-term facilitation and enhances apnea frequency in newborn rats. Am J Physiol Regul Integr Comp Physiol 294:R1356-R1366. CrossRef Medline

Kapoor A, Matthews SG (2005) Short periods of prenatal stress affect growth, behaviour and hypothalamo-pituitary-adrenal axis activity in male guinea pig offspring. J Physiol 566:967-977. CrossRef Medline

Katz-Salamon M (2004) Delayed chemoreceptor responses in infants with apnoea. Arch Dis Child 89:261-266. CrossRef Medline

Khemiri H, Seaborn T, Gestreau C, Soliz J (2012) Erythropoietin and its antagonist regulate hypoxic fictive breathing in newborn mice. Respir Physiol Neurobiol 183:115-121. CrossRef Medline

Kinney DK, Munir KM, Crowley DJ, Miller AM (2008) Prenatal stress and risk for autism. Neurosci Biobehav Rev 32:1519-1532. CrossRef Medline

Kinney HC (2009) Brainstem mechanisms underlying the sudden infant death syndrome: evidence from human pathologic studies. Dev Psychobiol 51:223-233. CrossRef Medline

Kinney HC, Thach BT (2009) The sudden infant death syndrome. N Engl J Med 361:795-805. CrossRef Medline

Kinney HC, Richerson GB, Dymecki SM, Darnall RA, Nattie EE (2009) The brainstem and serotonin in the sudden infant death syndrome. Annu Rev Pathol 4:517-550. CrossRef Medline

Kitayama I, Cintra A, Janson AM, Fuxe K, Agnati LF, Eneroth P, Aronsson M, Harfstrand A, Steinbush HW, Visser TJ, Goldstein M, Vale, W, Gustafsson JA (1989) Chronic immobilization stress: evidence for decreases of 5-hydroxy-tryptamine immunoreactivity and for increases of glucocorticoid receptor immunoreactivity in various brain regions of the male rat. Neural Transm 77:93-130. CrossRef Medline

Leiter JC, Böhm I (2007) Mechanisms of pathogenesis in the sudden infant death syndrome. Respir Physiol Neurobiol 159:127-138. CrossRef Medline

Lipton JW, Davidson TL, Carvey PM, Weese-Mayer DE (1996) Prenatal cocaine: effect on hypoxic ventilatory responsiveness in neonatal rats. Respir Physiol 106:161-169. CrossRef Medline

Mage DT, Donner M (2006) Female resistance to hypoxia: does it explain the sex difference in mortality rates? J Womens Health (Larchmt) 15:786794. CrossRef Medline

Manzke T, Dutschmann M, Schlaf G, Mörschel M, Koch UR, Ponimaskin E, Bidon O, Lalley PM, Richter DW (2009) Serotonin targets inhibitory synapses to induce modulation of network functions. Philos Trans R Soc B Biol Sci 364:2589-2602. CrossRef Medline

Montandon G, Bairam A, Kinkead R (2006) Long-term consequences of neonatal caffeine on ventilation, occurrence of apneas, and hypercapnic chemoreflex in male and female rats. Pediatr Res 59:519-524. CrossRef Medline

Mortola JP, Dotta A (1992) Effects of hypoxia and ambient temperature on gaseous metabolism of newborn rats. Am J Physiol 263:R267-R272. Medline

Moss IR, Laferrière A, Faltus RE (1995) Prenatal cocaine alters diaphragmatic EMG responses to hypoxia in developing swine. Am J Respir Crit Care Med 152:1961-1966. Medline

Muneoka K, Mikuni M, Ogawa T, Kitera K, Kamei K, Takigawa M, Takahashi K (1997) Prenatal dexamethasone exposure alters brain monoamine metabolism and adrenocortical response in rat offspring. Am J Physiol 273:R1669-R1675. Medline

Ozawa Y, Okado N (2002) Alteration of serotonergic receptors in the brain stems of human patients with respiratory disorders. Neuropediatrics 33 : 142-149. CrossRef Medline

Papaioannou A, Dafni U, Alikaridis F, Bolaris S, Stylianopoulou F (2002) Effects of neonatal handling on basal and stress-induced monoamine levels in the male and female rat brain. Neuroscience 114:195-206. CrossRef Medline

Paterson DS, Hilaire G, Weese-Mayer DE (2009) Medullary serotonin defects and respiratory dysfunction in sudden infant death syndrome. Respir Physiol Neurobiol 168:133-143. CrossRef Medline
Peters DA (1982) Prenatal stress: effects on brain biogenic amine and plasma corticosterone levels. Pharmacol Biochem Behav 17:721-725. CrossRef Medline

Poets CF (2010) Apnea of prematurity: what can observational studies tell us about pathophysiology? Sleep Medicine 11:701-707. CrossRef Medline

Ponirakis A, Susman EJ, Stifter CA (1998) Negative emotionality and cortisol during adolescent pregnancy and its effects on infant health and autonomic nervous system reactivity. Dev Psychobiol 33:163-174. CrossRef Medline

Ramanathan R, Corwin MJ, Hunt CE, Lister G, Tinsley LR, Baird T, Silvestri JM, Crowell DH, Hufford D, Martin RJ, Neuman MR, Weese-Mayer DE, Cupples LA, Peucker M, Willinger M, Keens TG, Group fTCHIMES (2001) Cardiorespiratory events recorded on home monitors. JAMA 285:2199-2207. CrossRef Medline

Richter DW, Manzke T, Wilken B, Ponimaskin E (2003) Serotonin receptors: guardians of stable breathing. Trends Mol Med 9:542-548. CrossRef Medline

Rigatto H (1992) Maturation of breathing control in the fetus and newborn infant. In: Respiratory control disorders in infants and children (Beckerman RC, Brouilette RT, Hunt CE, eds), pp 61-75. Baltimore: Williams and Wilkins.

Ruangkittisakul A, Secchia L, Bornes TD, Palathinkal DM, Ballanyi K (2007) Dependence on extracellular $\mathrm{Ca}^{2+} / \mathrm{K}^{+}$antagonism of inspiratory centre rhythms in slices and en bloc preparations of newborn rat brainstem. J Physiol 584:489-508. CrossRef Medline

Saetta M, Mortola JP (1987) Interaction of hypoxic and hypercapnic stimuli on breathing pattern in the newborn rat. J Appl Physiol 62:506-512. Medline

Slotkin TA, Barnes GA, McCook EC, Seidler FJ (1996) Programming of brainstem serotonin transporter development by prenatal glucocorticoids. Dev Brain Res 93:155-161. CrossRef Medline

Stanulis ED, Matulka RA, Jordan SD, Rosecrans JA, Holsapple MP (1997) Role of corticosterone in the enhancement of the antibody response after acute cocaine administration. J Pharmacol Exp Ther 280:284-291. Medline

Talge NM, Neal C, Glover V (2007) Antenatal maternal stress and longterm effects on child neurodevelopment: how and why? J Child Psychol Psychiatry 48:245-261. CrossRef Medline

Vázquez DM, López JF, Van Hoers H, Watson SJ, Levine S (2000) Maternal deprivation regulates serotonin $1 \mathrm{~A}$ and $2 \mathrm{~A}$ receptors in the infant rat. Brain Res 855:76-82. CrossRef Medline

Viemari JC, Roux JC, Tryba AK, Saywell V, Burnet H, Peña F, Zanella S, Bévengut M, Barthelemy-Requin M, Herzing LB, Moncla A, Mancini J, Ramirez JM, Villard L, Hilaire G (2005) Mecp2 deficiency disrupts norepinephrine and respiratory systems in mice. J Neurosci 25:11521-11530. CrossRef Medline

Voituron N, Shvarev Y, Menuet C, Bevengut M, Fasano C, Vigneault E, El Mestikawy S, Hilaire G (2010) Fluoxetine treatment abolishes the in vitro respiratory response to acidosis in neonatal mice. PLoS One 5:e13644. CrossRef Medline

Wainwright PE, Leatherdale ST, Dubin JA (2007) Advantages of mixed effects models over traditional ANOVA models in developmental studies: a worked example in a mouse model of fetal alcohol syndrome. Dev Psychobiol 49:664-674. CrossRef Medline

Weisz J, Ward IL (1980) Plasma testosterone and progesterone titers of pregnant rats, their male and female fetuses, and neonatal offspring. Endocrinology 106:306-316. CrossRef Medline

Zanella S, Watrin F, Mebarek S, Marly F, Roussel M, Gire C, Diene G, Tauber M, Muscatelli F, Hilaire G (2008) Necdin plays a role in the serotonergic modulation of the mouse respiratory network: implication for PraderWilli syndrome. J Neurosci 28:1745-1755. CrossRef Medline

Zhao J, Gonzalez F, Mu D (2011) Apnea of prematurity: from cause to treatment. Eur J Pediatr 170:1097-1105. CrossRef Medline

Zorrilla EP (1997) Multiparous species present problems (and possibilities) to developmentalists. Dev Psychobiol 30:141-150. CrossRef Medline 